\title{
Effects of Microbial Aerosol in Poultry House on Meat Ducks' Immune Function
}

\author{
Guanliu Yu ${ }^{1}$, Yao Wang ${ }^{1}$, Shouguo Wang ${ }^{2}$, Changmin Duan ${ }^{2}$, Liangmeng Wei ${ }^{1}$, Jing Gao ${ }^{3}$, \\ Tongjie Chai ${ }^{1 *}$ and Yumei Cai ${ }^{1 *}$ \\ ${ }^{1}$ College of Animal Science and Veterinary Medicine, Shandong Agricultural University, Sino-German Cooperative Research \\ Centre for Zoonosis of Animal Origin Shandong Province, Tai'an, China, ${ }^{2}$ Deizhou People's Hospital, Deizhou, China, \\ ${ }^{3}$ The Central Hospital of Tai'an, Tai'an, China
}

\section{OPEN ACCESS}

Edited by:

Haruki Kitazawa,

Tohoku University, Japan

Reviewed by:

Graciela Alicia Cremaschi, Institute of Biomedical Research,

National Research Council of

Argentina, Argentina

Jessica Lynn Humann,

Florida A\&M University, USA

*Correspondence:

Tongjie Cha

chaitj117@163.com

Yumei Cai

caiyum@163.com

Specialty section:

This article was submitted to

Microbial Immunology,

a section of the journal

Frontiers in Microbiology

Received: 21 April 2016

Accepted: 27 July 2016

Published: 17 August 2016

Citation:

Yu G, Wang Y, Wang S, Duan C, Wei L, Gao J, Chai T and Cai Y (2016) Effects of Microbial Aerosol in Poultry House on Meat Ducks' Immune

Function. Front. Microbiol. 7:1245. doi: 10.3389/fmicb.2016.01245
The aim of this study was to evaluate effects of microbial aerosols on immune function of ducks and shed light on the establishment of microbial aerosol concentration standards for poultry. A total of 1800 1-d-old cherry valley ducks were randomly divided into five groups ( $A, B, C, D$, and E) with 360 ducks in each. To obtain objective data, each group had three replications. Concentrations of airborne bacteria, fungi, endotoxin in different groups were created by controlling ventilation and bedding cleaning frequency. Group A was the control group and hygienic conditions deteriorated progressively from group B to E. A 6-stage Andersen impactor was used to detect the aerosol concentration of aerobes, gram-negative bacteria, fungi, and AGl-30 microbial air sampler detect the endotoxin, and Composite Gas Detector detect the noxious gas. In order to assess the immune function of meat ducks, immune indicators including H5 AIV antibody titer, IgG, IL-2, T-lymphocyte transformation rate, lysozyme and immune organ indexes were evaluated. Correlation coefficients were also calculated to evaluate the relationships among airborne bacteria, fungi, endotoxin, and immune indicators. The results showed that the concentration of airborne aerobe, gram-negative bacteria, fungi, endotoxin have a strong correlation to H5 AIV antibody titer, IgG, IL-2, T-lymphocyte transformation rate, lysozyme, and immune organ indexes, respectively. In addition, when the concentration of microbial aerosol reach the level of group D, serum lgG (6-8 weeks), lysozyme (4 week) were significantly higher than in group $A(P<0.05)$; serum IL-2 (7 and 8 weeks), T-lymphocyte transformation rate, lysozyme ( 7 and 8 weeks), spleen index ( 6 and 8 weeks), and bursa index (8 week) were significantly lower than in group $\mathrm{A}$ ( $P<0.05$ or $P<0.01)$. The results indicated that a high level of microbial aerosol adversely affected the immune level of meat ducks. The microbial aerosol values in group $D$ provide a basis for recommending upper limit concentrations of microbial aerosols for healthy meat ducks.

Keywords: microbial aerosol, immune indicators, stress, cherry valley ducks, poultry houses 


\section{INTRODUCTION}

The air in poultry houses is usually heavily contaminated by large quantities of airborne microorganisms, endotoxins and toxic gases $\left(\mathrm{NH}_{3}, \mathrm{H}_{2} \mathrm{~S}\right)$, etc. (Nimmermark et al., 2009; CambraLópez et al., 2010; Lawniczek-Walczyk et al., 2013). In airborne microorganisms, there is a high concentration of non-pathogenic microorganisms leading to animal immunosuppression (Douwes et al., 2003; Fiegel et al., 2006). The high level of airborne aerobe could reduce animal immunity and growth rate (Wolinsky, 2006). Many studies have documented that exposure to fungal aerosol may be associated with asthma, acute toxic and allergic, and it may threaten caretakers and external ambient in animal houses as well (Bush and Portnoy, 2001; Pavan and Manjunath, 2014). The percentage of airborne gram-negative bacteria in the bacterial aerosol is small, but it contains a lot of pathogenic bacteria (Zucker et al., 2000). Endotoxins are ubiquitous in the environment. They are a biologically active lipopolysaccharide that is a component of the outer membrane of gram-negative bacteria (Balasubramanian et al., 2012). According to Pirie, inhaled endotoxin contributes significantly to the induction of airway inflammation and dysfunction (Pirie et al., 2003). Many occupational studies have shown positive associations between endotoxin exposure and respiratory disorders including asthmalike syndrome, chronic airway obstruction, organic duct toxic syndrome, byssinosis, bronchitis, etc. (Madsen, 2006). Zucker et al. have used it as an important symbol of organic dust in the air of poultry house (Zucker et al., 2000). Endotoxin also affects human humoral and cellular immunity (Burrell, 1990). Furthermore, in terms of toxic gases in animal house, ammonia and hydrogen sulfide are two well-known toxic components (Yao and $\mathrm{Li}, 2010$ ). They can cause respiratory, eye diseases and even poisoning death (Teye et al., 2008; Yao and Li, 2010; Barrasa et al., 2012).

To date, numerous correlation studies have focused on microbial aerosol composition, concentration and mechanisms of spread to the surrounding ambient (Zucker et al., 2000; Madsen, 2006; Duan et al., 2007; Masclaux et al., 2013; Matković et al., 2013). However, studies of microbial aerosol on immune function have not been found. Therefore, the aim of this study was to clarity the effect of microbial aerosol on the immune function of ducks, which was based on comparing the significance between control group and the treatment groups of ducks' specific immune indexes (e.g., IgG, H5 AIV antibody titer, IL-2, etc.) and the non-specific immune factors (e.g., lysozyme), as well as the relationship between major microbial aerosol concentration and immune indicators. Moreover, this study also could enlighten future studies on the establishment of microbial aerosol concentration standards for poultry breeding.

\section{MATERIALS AND METHODS}

\section{Experimental Design}

This study was conducted at the Animal Husbandry \& Veterinary Station of Shandong Agricultural University, China during January-March, 2014. Five groups were set up, with a control group A and 4 treatment groups (B, C, D, and E, with hygienic conditions deteriorating progressively from group B to E). Each group had three replications with each in a separate poly-tunnel. The poly-tunnel is covered by a double layer of clear plastic with $2 \mathrm{~cm}$ insulation in between and with steel or wood arch frames and bedding on the ground. It is naturally ventilated and the duck feces are cleaned manually. All 15 poly-tunnels were identical, equipped with similar exhaust fan, radiator and incandescent light bulb $(80 \mathrm{~W})$. Air warmed by the heat from the sun in the day and the bulb at night was retained in the building by the roof and walls. Temperature of each group was maintained between 20 and $24^{\circ} \mathrm{C}$ using radiators and exhaust fan. A regime of 16 h light (between 05:00 and 21:00) and $8 \mathrm{~h}$ darkness was used, with a 25 min twilight phase at the end of each day, and light intensity was about $60 \mathrm{~lx}$ at bird-eye height. The size of poly-tunnel was $4.0 \times 4.0 \times 3.0 \mathrm{~m}$, with a window $(2.0 \times 1.5 \mathrm{~m})$ facing the sun. A glass door $(0.8 \times 1.8 \mathrm{~m})$ was used to observe the behavior of ducks in each poly-tunnel. A total of 18001 -day old cherry valley ducks were placed in the ducks houses, with 360 ducks in each poly-tunnel. The ducks were reared on the floor with thick bedding (wood-shavings), and food and water were automatically refilled. Phosphoric acid $\left(\mathrm{H}_{3} \mathrm{PO}_{4}\right)$, calcium superphosphate $\left[\mathrm{Ca}\left(\mathrm{H}_{2} \mathrm{PO}_{4}\right)_{2}\right]$, ferrous sulfate $\left(\mathrm{FeSO}_{4} \cdot 7 \mathrm{H}_{2} \mathrm{O}\right)$, caustic lime $(\mathrm{CaO})$, acticarbon and alum $\left[\mathrm{Al}_{2}\left(\mathrm{SO}_{4}\right)_{3} \cdot 18 \mathrm{H}_{2} \mathrm{O}\right]$ were used to absorb noxious gases (such as $\mathrm{NH}_{3}$; Moore et al., 1996; Do et al., 2005; Yao and Li, 2010). Before the trial began, environmental management measures under rearing conditions in poly-tunnels in North China were investigated, while health management measures in different groups were examined. Based on these findings, the health management measures of all treatment groups in this experiment are listed (Table 1; Yu et al., 2016). All animal experiments were performed according to the guidelines of the Committee on the Ethics of Animals of Shandong and the appropriate biosecurity guidelines, and the protocol was approved by Shandong Agricultural University Animal Care and Use Committee (No. SDAUA-2014-066).

\section{Sample Collection and Analysis Determination of Airborne Aerobe, Fungi, and Gram-Negative Bacteria}

A 6-stage Andersen impactor (airflow $28.3 \mathrm{~L} / \mathrm{min}$ ), at a height of about $0.2 \mathrm{~m}$ (duck's breathing zone) above the ground in the central part of each poly-tunnel, was used to sample airborne aerobe, fungi and gram-negative bacteria weekly at 7:00, 14:00,

TABLE 1 | Management regimes in different groups.

\begin{tabular}{llcl}
\hline Groups & $\begin{array}{l}\text { Ventilation } \\
\text { method }\end{array}$ & $\begin{array}{c}\text { Ventilation } \\
\text { time } \mathbf{( h )}\end{array}$ & $\begin{array}{l}\text { Frequency of troughs } \\
\text { cleaning, sterilization, } \\
\text { and bedding replacement }\end{array}$ \\
\hline A (Control) & $\begin{array}{l}\text { Natural and } \\
\text { mechanical }\end{array}$ & 24 & Once/day \\
B (Treatment) & Mechanical & 24 & Once/2 days \\
C (Treatment) & Mechanical & 18 & Once/3 days \\
D (Treatment) & Mechanical & 12 & Once/4 days \\
E (Treatment) & Mechanical & 10 & Once/5 days
\end{tabular}


and 20:00 h, respectively. The samples were selected three times for 1-2 min a time in every poly-tunnel. Soy agar medium with $5 \%$ defibrinated sheep blood, Sabouraud's medium (HB02538, Hope Bio-Technology Co., Ltd, Qingdao, China) and a gram-negative bacteria selective medium (HB8643, Hope BioTechnology Co., Ltd, Qingdao, China) were used as sampling media for aerobes, fungi, and gram-negatives, respectively. For Sabouraud's medium, after high temperature steam sterilization, add Chloramphenicol (dose is $0.2 \mathrm{~g} / \mathrm{L}$ ) into it. The samples were taken to the microbe laboratory and cultured in incubators (aerobic condition)-the aerobes at $37^{\circ} \mathrm{C}$ for 1 day, fungi at $25^{\circ} \mathrm{C}$ for 4 days and gram-negative bacteria at $37^{\circ} \mathrm{C}$ for 3 days. After incubation, the numbers of colonies on plates were determined with a Colony Star counter and concentrations were expressed as colony forming units per $\mathrm{m}^{3}$ (CFU/ $\mathrm{m}^{3}$; Andersen, 1958).

\section{Determination of Airborne Endotoxin}

Air samples for endotoxin were collected by the AGI-30 Sampler (airflow $12.5 \mathrm{~L} / \mathrm{min}$ ) weekly at the height of $0.2 \mathrm{~m}$ (Duck's breathing zone) for $20 \mathrm{~min}$, with $50 \mathrm{~mL}$ pyrogen-free water as media (Brachmann et al., 1964). Sampling sites were set in the central part of each poly-tunnel. Endotoxin content was determined by Limulus amebocyte lysate (LAL) assay (QLC2100 Bio Whittaker, Walkersville, MD, USA). A standard curve obtained from an Escherichia was used to express concentrations as endotoxin units (EU) which were presented as $\mathrm{EU} / \mathrm{m}^{3}$.

\section{Determination of Noxious Gas}

Noxious gas was detected by Composite Gas Detector (GC310, Chicheng Electric Co., Ltd, Henan, China) in all groups in real time. The instrument was hung $0.2 \mathrm{~m}$ above the ground on the wall. The concentration of noxious gas was presented as $\mathrm{mg} / \mathrm{Kg}$.

\section{Determination of Immune Indicators}

At the age of 10 days, ducks were immunized with H5 AIV vaccine (Reassortant Avian Influenza Virus H5 Subtype Vaccine, Inactivated Strain Re-6+Strain Re-4, Qingdao Yebio Biological Engineering Co., Ltd., Qingdao, China) by neck subcutaneous, $1.5 \mathrm{~mL}$ of each one.

Five $\mathrm{mL}$ of blood sample was collected in EDTA vacuum tubes through vena digitalis from each duck of 4-, 5-, 6-, 7- and 8-week old (60 ducks in each group). After centrifugation for $10 \mathrm{~min}$ at $800 \mathrm{~g}$, serum samples were stored at $-20^{\circ} \mathrm{C}$ until analysis. Duck IgG detection kit, duck IL-2 detection kit (both of them were purchased from Nanjing SenBenJia Biological Technology Co., Ltd. Nanjing, China), lysozyme detection kit (Nanjing Jiancheng Bioengineering Institute, Nanjing, China) and hemagglutinationinhibition (HI) test were used to detect the serum IgG, IL-2, lysozyme and H5 AIV antibody titer, respectively.

MTT (Methy Thiazolyl Tetrazolium) colorimetric assay was used to detect $\mathrm{T}$ lymphocytes transformation rate (Lazar et al., 2010; Hsiao and Huang, 2011; Yin et al., 2015). The procedure as follows:

One $\mathrm{mL}$ of blood sample was collected in EDTA vacuum tubes through vena digitalis from each duck of 4-, 5-, 6-, 7-, and 8-week old (60 ducks in each group).
One $\mathrm{mL}$ whole blood dilution (Shanghai Yanjin Biotechnology Co.Ltd. Shanghai, China) was added to the above blood sample $(1 \mathrm{~mL})$, then mixed. The mixture was added on $4 \mathrm{~mL}$ lymphocyte separation fluid (Beijing Dingguo Chengsheng Biotechnology Co., Ltd. Beijing, China) for $15 \mathrm{~min}$ centrfugation at $800 \mathrm{~g}$. The white coat that under the plasma layer was sucked out and washed 2 times with 3-5 times volume RPMI 1640 culture liquid (Sigma, USA) without calf serum, each time with centrfugation for $10 \mathrm{~min}$ at $800 \mathrm{~g}$.

Counting with Trypan Blue (Sigma, USA), the living cells was more than 95\%. Single cell suspensions (final concentration was $3 \times 10^{6} / \mathrm{mL}$ ) were prepared by RPMI 1640 complete culture liquid containing $10 \%$ calf serum. The single cell suspension was cultured in a cell incubator at $37^{\circ} \mathrm{C}, 6.5 \% \mathrm{CO}_{2}$ for $14 \mathrm{~h}$. Peripheral blood lymphocyte were obtain and then prepared for lymphocyte suspension (final concentration was $2 \times 10^{6} / \mathrm{mL}$ ).

Cells are grown in microtiter plates (tissue culture grade, 96 wells, flat bottom). $100 \mu \mathrm{L}$ of the lymphocyte suspension and $100 \mu \mathrm{L}$ of the PHA (phytohaemagglutinin; Beijing Baiaosentai Biotechnology Co., Ltd. Beijing, China; final concentration was $25 \mu \mathrm{g} / \mathrm{mL}$ ) was added (final concentration was $2 \times 10^{6}$ $/ \mathrm{mL}$ ) into each test well. $100 \mu \mathrm{L}$ of the lymphocyte suspension and $100 \mu \mathrm{L}$ of the RPMI 1640 was added into each control well. The replications is five. After the incubation in a cell incubator at $37^{\circ} \mathrm{C}, 6.5 \% \mathrm{CO}_{2}$ for $44 \mathrm{~h}, 20 \mu \mathrm{L}$ of MTT (5 $\mathrm{mg} / \mathrm{mL}$ ) was added into each well and then continued to incubate for $4 \mathrm{~h}$. The supernatant of each well was discarded carefully.

After that, $150 \mu \mathrm{L}$ of dimethyl sulfoxide was added into each well and then oscillated for $10 \mathrm{~min}$ on microoscillator. The value of OD $570 \mathrm{~nm}$ was measured by Microplate Reader (Antai AY858, Shanghai, China).

$$
\begin{aligned}
& \text { T-lymphocyte transformation rate }= \\
& \frac{\text { Mean value of test } \mathrm{OD}_{570}}{\text { Mean value of control } \mathrm{OD}_{570}} \times 100 \%
\end{aligned}
$$

\section{Determination of Immune Organ Indexes}

The ducks of 4-, 6-, 8-week were weighed and recorded (60 ducks in each group). After that, thymus, spleen and bursa were collected from those ducks, respectively, and then weighed and recorded. At last, the immune organ indexes were calculated according to the follow formula.

$$
\text { Immune organ indexes }=\frac{\text { Immune organ }(\mathrm{g})}{\text { Body weight }(\mathrm{Kg})} \times 100 \%
$$

\section{Statistical Analysis}

Data collection ran from week 4 to week 8. Data for each group were expressed as the mean of three replications. The maximum, minimum and median value were used for the air ambient parameter (Duan et al., 2007). All statistical analyses were performed using SAS 9.1 Software (SAS Institute, Inc., Cary, NC, USA). One-way ANOVA analysis with multiple-range test was used to evaluate the difference among groups (Duncan, 1955). Results are expressed as mean \pm standard deviation (SD). Correlation between major microbial concentrations and 
immune indicators were analyzed by Pearson's. $P<0.05$ was considered statistically significant.

\section{RESULTS}

\section{The Concentrations of Microbial Aerosol and Noxious Gas under Different Hygienic Conditions}

Over time, the concentrations of airborne aerobe, airborne fungi, airborne gram-negative, airborne endotoxin, and $\mathrm{NH}_{3}$ showed an overall trend of increase with the deteriorating of hygienic conditions, however, concentration of $\mathrm{NH}_{3}$ in each group was lower than the poultry harmless criterion $(10 \mathrm{ppm}$, GB/T 18407.3-2001), and $\mathrm{H}_{2} \mathrm{~S}$ was not found in all groups (Table 2; Yu et al., 2016).

\section{The Effect of Microbial Aerosol on Specific Immunity of Meat Ducks}

\section{H5 AIV Antibody Titer}

Under the condition without booster immunization, the H5 AIV antibody titer in serum of meat ducks of groups A and B reached a peak at week $5(6.00 \pm 1.00$ and $6.33 \pm 1.53$, respectively),

TABLE 2 | Airborne aerobe, airborne fungi, airborne gram-negative bacteria, airborne endotoxin, and noxious gas concentrations under different hygienic conditions.

\begin{tabular}{|c|c|c|c|c|c|c|}
\hline \multirow[t]{2}{*}{ Parameter } & \multirow[t]{2}{*}{ Value } & \multicolumn{5}{|c|}{ Groups } \\
\hline & & A & B & C & D & $\mathbf{E}$ \\
\hline \multirow{3}{*}{$\begin{array}{l}\text { Aerobe }(\times 10 \text { E5 } \\
\text { CFU/mE3) }\end{array}$} & Minimum & 0.46 & 0.69 & 0.68 & 0.59 & 0.71 \\
\hline & Maximum & 2.30 & 5.10 & 5.76 & 5.96 & 8.96 \\
\hline & Mean & 1.05 & 2.45 & 2.94 & 2.96 & 4.31 \\
\hline \multirow{3}{*}{$\begin{array}{l}\text { Fungi (×10E4 } \\
\text { CFU/mE3) }\end{array}$} & Minimum & 0.11 & 0.21 & 0.19 & 0.85 & 0.78 \\
\hline & Maximum & 3.49 & 3.54 & 3.95 & 5.73 & 8.05 \\
\hline & Mean & 1.02 & 1.32 & 1.44 & 2.63 & 3.07 \\
\hline \multirow{3}{*}{$\begin{array}{l}\text { Gram-negative bacteria } \\
(\times 10 \mathrm{E} 4 \mathrm{CFU} / \mathrm{mE} 3)\end{array}$} & Minimum & 0.20 & 0.32 & 0.36 & 0.89 & 0.98 \\
\hline & Maximum & 2.04 & 1.95 & 3.62 & 8.87 & 5.03 \\
\hline & Mean & 0.93 & 1.24 & 1.68 & 3.09 & 2.64 \\
\hline \multirow{3}{*}{$\begin{array}{l}\text { Endotoxin }(\times 10 \text { E3 } \\
\text { EU/mE3) }\end{array}$} & Minimum & 0.20 & 0.40 & 0.28 & 0.13 & 0.56 \\
\hline & Maximum & 25.6 & 72.4 & 102.4 & 144.8 & 144.8 \\
\hline & Mean & 6.49 & 10.48 & 23.03 & 41.78 & 47.79 \\
\hline \multirow[t]{3}{*}{$\mathrm{NH}_{3}(\mathrm{mg} / \mathrm{Kg})$} & Minimum & 0 & 0 & 2 & 4 & 4 \\
\hline & Maximum & 4 & 12 & 10 & 15 & 14 \\
\hline & Mean & 2.56 & 2.42 & 5.67 & 9.48 & 8.97 \\
\hline \multirow[t]{3}{*}{$\mathrm{H}_{2} \mathrm{~S}(\mathrm{mg} / \mathrm{Kg})$} & Minimum & $--^{a}$ & - & - & - & - \\
\hline & Maximum & - & - & - & - & - \\
\hline & Mean & - & - & - & - & - \\
\hline
\end{tabular}

All value for total experimental period.

${ }^{a}$ Below the limit of detection.

The bold values could be used as a basis for recommending upper limit concentrations of microbial aerosols for healthy meat ducks. however, groups $\mathrm{C}, \mathrm{D}$, and $\mathrm{E}$ reached the peak at weeks 6,7 , and $8(5.00 \pm 1.00,4.33 \pm 1.53$, and $3.00 \pm 2.00$, respectively; Figure 1). At the same week age, with the microbial aerosol concentrations increasing, the concentration of H5 AIV antibody titer in the serum of meat ducks generally showed a tendency of decline.

Serum H5 AIV antibody titers were lower in groups $\mathrm{E}$ than in group $\mathrm{A}(P<0.01)$ at weeks 4 and 7 ; groups $\mathrm{E}$ were lower than group $\mathrm{A}(P<0.05)$ at weeks 5 and 6 .

\section{$\lg G$}

At the same week age, with the increase of the microbial aerosol concentrations, the concentration of IgG in serum of meat ducks generally showed a tendency of increase (Figure 2).

Concentration of serum IgG were higher in groups $E$ than in groups $\mathrm{A}(P<0.05)$ at week 4 and 5 ; groups $\mathrm{D}$ were higher than

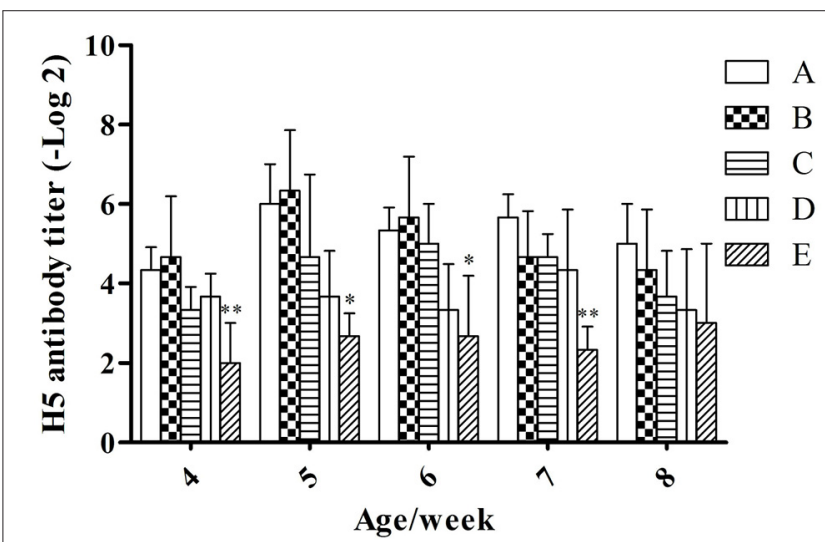

FIGURE 1 | H5 AIV antibody titer under different hygienic conditions $(\boldsymbol{n}=\mathbf{6 0})$. Note: The comparison was between treatment groups $(\mathrm{B}-\mathrm{E})$ and control group (A) at the same age/week, ${ }^{*} P<0.05$ and ${ }^{\star \star} P<0.01$. The same as below. ${ }^{*}$ Means that the difference between treatment groups $(B-E)$ and control group (A) was significant.

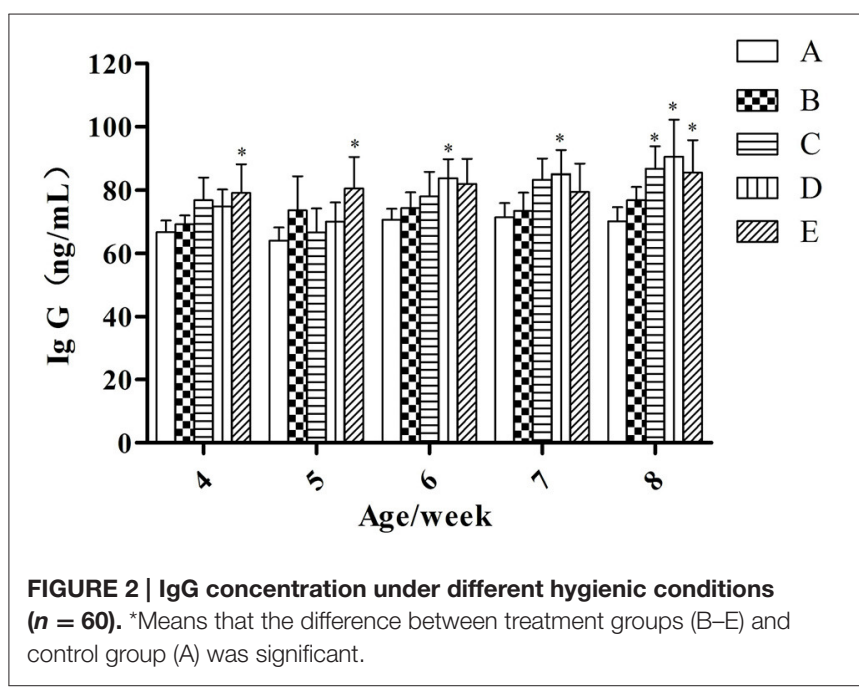


group A $(P<0.05)$ at week 6 and 7; groups $\mathrm{C}, \mathrm{D}$, and $\mathrm{E}$ were higher than group A $(P<0.05)$ at week 8 .

\section{IL-2}

At the same week age, with the increase of the microbial aerosol concentrations, the concentration of IL-2 in serum of meat ducks generally showed a tendency of decline (Figure 3).

Serum IL-2 in groups E were lower than in group A $(P<0.05)$ at week 4 and 6; groups $\mathrm{D}$ and $\mathrm{E}$ were lower than group $\mathrm{A}$ $(P<0.01)$ at week 7; groups $\mathrm{D}$ and $\mathrm{E}$ were lower than group A $(P<0.05$ and $P<0.01$, respectively $)$ at week 8 .

\section{T-Lymphocyte Transformation Rate}

At the same week age, with the increase of the microbial aerosol concentrations, T-lymphocyte transformation rate of meat ducks generally showed a tendency of decline (Figure 4), and the decline range was obvious.

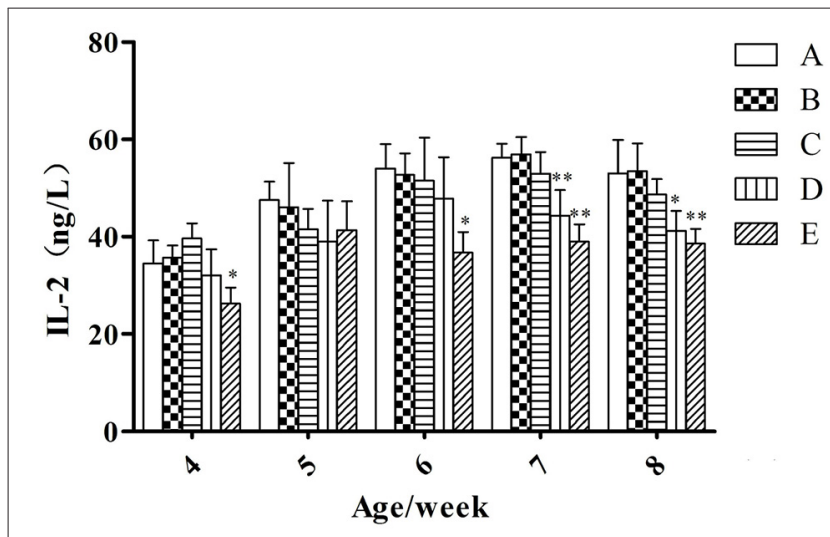

FIGURE 3 | IL-2 concentration under different hygienic conditions $(\boldsymbol{n}=\mathbf{6 0})$. *Means that the difference between treatment groups $(B-E)$ and control group (A) was significant. ${ }^{*}$ Means that the difference between treatment groups (B-E) and control group (A) was extremely significant.

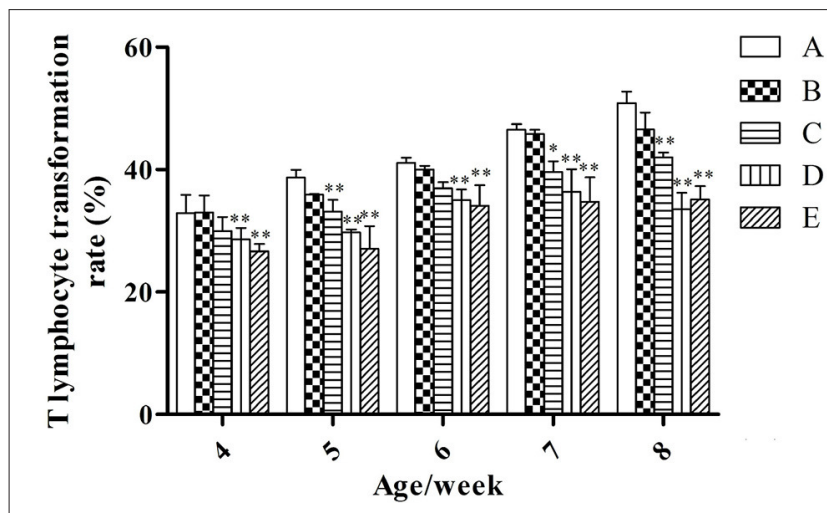

FIGURE 4 | T-lymphocyte transformation rate under different hygienic conditions $(\boldsymbol{n}=\mathbf{6 0})$. " Means that the difference between treatment groups $(B-E)$ and control group (A) was significant. ${ }^{* *}$ Means that the difference between treatment groups $(B-E)$ and control group $(A)$ was extremely significant.
T-lymphocyte transformation rates of groups $\mathrm{D}$ and $\mathrm{E}$ were lower than that of group A $(P<0.01)$ at weeks 4 and 6 ; groups $\mathrm{C}, \mathrm{D}$, and $\mathrm{E}$ were lower than that of group $\mathrm{A}(P<0.01)$ at weeks 5 and 8; groups $\mathrm{C}, \mathrm{D}$, and $\mathrm{E}$ were lower than that of group A $(P<0.05, P<0.01$ and $P<0.01$, respectively $)$ at week 7.

\section{The Effect of Microbial Aerosol on Non-specific Immunity of Meat Ducks Lysozyme}

At the same week age, as microbial aerosol concentrations increasing, the concentration of lysozyme in serum of meat ducks generally showed a tendency of increase at first (at weeks 4 and 5 ) and then showed a tendency of decline (at weeks 6, 7, and 8; Table 3).

Serum lysozyme in groups $\mathrm{D}$ and $\mathrm{E}$ were higher than group $\mathrm{A}$ $(P<0.05)$ at week 4; groups $\mathrm{B}, \mathrm{C}, \mathrm{D}$ and $\mathrm{E}$ were lower than group $\mathrm{A}(P<0.01)$ at week 7 ; groups $\mathrm{D}$ and $\mathrm{E}$ were lower than group $\mathrm{A}$ $(P<0.01)$, but the group $\mathrm{B}$ was higher than group $\mathrm{A}(P<0.01)$ at week 8 .

\section{Immune Organ Indexes}

At the same week age, with the increase of the microbial aerosol concentrations, the index of thymus, spleen and bursa of meat ducks generally showed a tendency of decline (Table 4).

For thymus index, there was no significant effect $(P>0.05)$. As for spleen index, groups $\mathrm{D}$ and $\mathrm{E}$ were lower than group $\mathrm{A}$ $(P<0.05)$ at week 6; groups $\mathrm{D}$ and $\mathrm{E}$ were lower than group $\mathrm{A}$ ( $P<0.05$ and $P<0.01$, respectively) at week 8 . For bursa index, groups $\mathrm{C}, \mathrm{D}$ and $\mathrm{E}$ were lower than group $\mathrm{A}(P<0.05)$ at week 8 .

\section{Relationships between Microbial Aerosol Constituents and Immune Indicators}

The correlation between microbial aerosol and immune indicators is shown in Table 5.

The concentration of aerobe showed a strong correlation to IgG, H5 AIV antibody titer, T-lymphocyte transformation rate, Thymus Index, Spleen Index and Bursa Index $(r=0.91$ at $P<0.05, r=-0.90$ at $P<0.05, r=-0.89$ at $P<0.05, r=$ -0.92 at $P<0.05, r=-0.94$ at $P<0.05, r=-0.88$ at $P<0.05$, respectively).

As for fungi, a significant negative correlation was recorded between fungi and H5 AIV antibody titer, IL-2, T-lymphocyte transformation rate, Lysozyme, Thymus Index, Spleen Index and Bursa Index $(r=0.95$ at $P<0.05, r=-0.99$ at $P<0.01, r=$ -0.95 at $P<0.05, r=-0.97$ at $P<0.01, r=-0.96$ at $P<0.01$, $r=-0.96$ at $P<0.01, r=-0.93$ at $P<0.05$, respectively).

The concentration of endotoxin revealed the same dependency on H5 AIV antibody titer, IL-2, T-lymphocyte transformation rate, Lysozyme, Thymus Index, Spleen Index, and Bursa Index $(r=0.98$ at $P<0.01, r=-0.99$ at $P<0.01$, $r=-0.95$ at $P<0.05, r=-0.97$ at $P<0.01, r=-0.98$ at $P<0.01, r=-0.95$ at $P<0.05, r=-0.89$ at $P<0.05$, respectively).

However, the gram-negative bacteria correlated negatively with IgG, IL-2, T-lymphocyte Transformation Rate, Lysozyme, 
TABLE 3 | Lysozyme concentration $(\mathrm{U} / \mathrm{mL})$ under different hygienic conditions $(n=60)$.

\begin{tabular}{|c|c|c|c|c|c|}
\hline \multirow[t]{2}{*}{ Weeks } & \multicolumn{5}{|c|}{ Groups } \\
\hline & A & B & C & D & $\mathbf{E}$ \\
\hline 4 & $120.14 \pm 4.22$ & $126.10 \pm 4.99$ & $124.60 \pm 9.73$ & $130.62 \pm 7.99^{\star}$ & $133.62 \pm 6.14^{\star}$ \\
\hline 5 & $148.32 \pm 5.21$ & $150.85 \pm 5.79$ & $149.22 \pm 6.68$ & $152.30 \pm 7.76$ & $156.83 \pm 9.35$ \\
\hline 6 & $153.72 \pm 6.77$ & $152.80 \pm 11.29$ & $158.16 \pm 8.43$ & $145.65 \pm 7.03$ & $148.98 \pm 9.43$ \\
\hline 7 & $176.42 \pm 6.43$ & $158.47 \pm 6.92^{\star \star}$ & $162.38 \pm 9.68^{\star \star}$ & $151.90 \pm 7.56^{\star \star}$ & $141.37 \pm 5.98^{\star \star *}$ \\
\hline 8 & $166.31 \pm 4.46$ & $180.53 \pm 6.65^{\star \star *}$ & $156.90 \pm 8.21$ & $144.82 \pm 8.60^{\star \star}$ & $139.43 \pm 7.34^{\star \star}$ \\
\hline
\end{tabular}

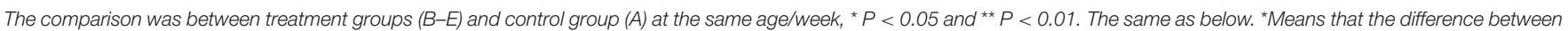
treatment groups $(B-E)$ and control group $(A)$ was significant. ${ }^{*}$ Means that the difference between treatment groups $(B-E)$ and control group $(A)$ was extremely significant.

TABLE 4 | Immune organ indexes under different hygienic conditions $(n=60)$.

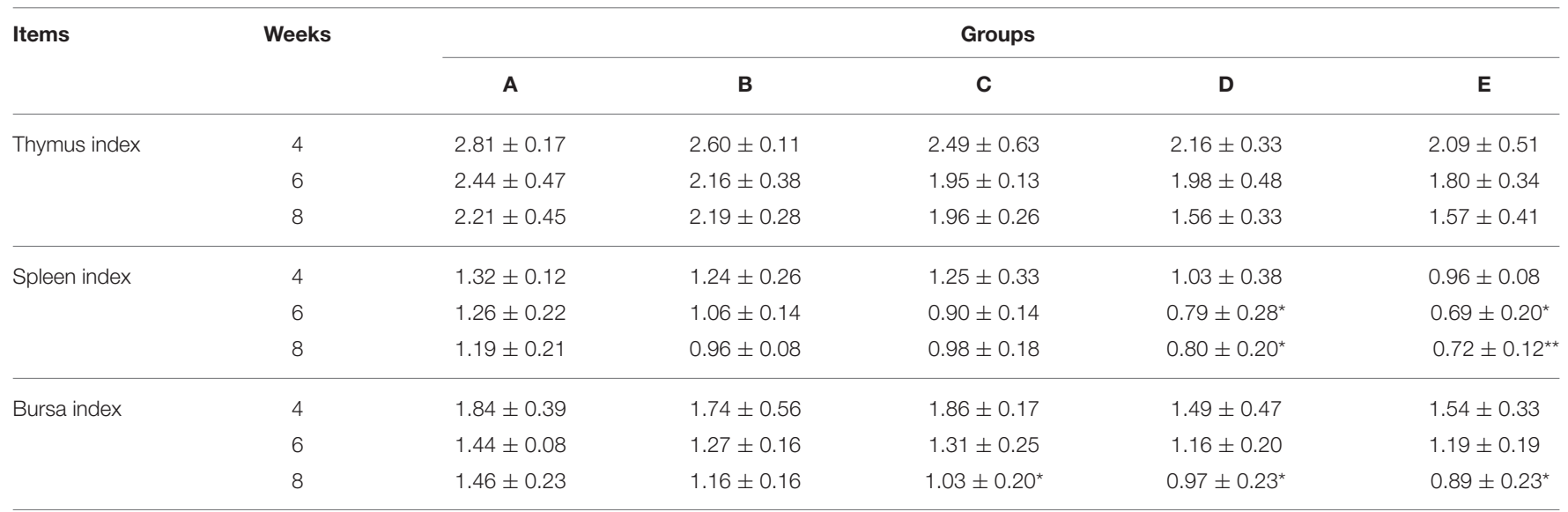

${ }^{*}$ Means that the difference between treatment groups $(B-E)$ and control group $(A)$ was significant. ${ }^{\star \star}$ Means that the difference between treatment groups $(B-E)$ and control group $(A)$ was extremely significant.

TABLE 5 | Correlation between concentrations of major microbial aerosol components and values of immune indicators.

\begin{tabular}{|c|c|c|c|c|}
\hline $\begin{array}{l}\text { Immune } \\
\text { index }\end{array}$ & Aerobe & Fungi & $\begin{array}{c}\text { Gram-negative } \\
\text { bacteria }\end{array}$ & Endotoxin \\
\hline $\lg G$ & $r=0.91^{*}$ & $r=0.86$ & $r=-0.90^{\star}$ & $r=0.86$ \\
\hline $\begin{array}{l}\text { H5 AIV } \\
\text { antibody titer }\end{array}$ & $r=-0.90^{\star}$ & $r=-0.95^{\star}$ & $r=-0.87$ & $r=-0.98^{\star \star}$ \\
\hline IL-2 & $r=-0.84$ & $r=-0.99^{\star \star}$ & $r=-0.88^{\star}$ & $r=-0.99^{\star \star}$ \\
\hline $\begin{array}{l}\text { T-lymphocyte } \\
\text { trans- } \\
\text { formation } \\
\text { rate }\end{array}$ & $r=-0.89^{\star}$ & $r=-0.95^{\star}$ & $r=-0.95^{\star}$ & $r=-0.95^{\star}$ \\
\hline Lysozyme & $r=-0.79$ & $r=-0.97^{\star \star}$ & $r=-0.95^{\star}$ & $r=-0.97^{\star \star}$ \\
\hline Thymus index & $r=-0.92^{\star}$ & $r=-0.96^{\star \star}$ & $r=-0.83$ & $r=-0.98^{\star \star}$ \\
\hline Spleen index & $r=-0.94^{\star}$ & $r=-0.96^{\star \star}$ & $r=-0.92^{\star}$ & $r=-0.95^{\star}$ \\
\hline Bursa index & $r=-0.88^{\star}$ & $r=-0.93^{\star}$ & $r=-0.94^{\star}$ & $r=-0.89^{\star}$ \\
\hline
\end{tabular}

Significant relationships $\left({ }^{\star} P<0.05,{ }^{* \star} P<0.01\right)$ expressed as Pearson correlation coefficients (r) in bold.

Spleen Index, and Bursa Index $(r=-0.90$ at $P<0.05, r=-0.88$ at $P<0.05, r=-0.95$ at $P<0.05, r=-0.95$ at $P<0.05, r=$ -0.92 at $P<0.05, r=-0.94$ at $P<0.05$, respectively).
The prediction models are as follows:

$\mathrm{Y}=75.49-2.78 \times 10 \mathrm{E}-6 \mathrm{X}_{1}+2.13 \times 10 \mathrm{E}-5 \mathrm{X}_{2}, R^{2}=0.3414$, $p=0.5086>0.05$

Y: $\operatorname{IgG}(\mathrm{ng} / \mathrm{mL}) ; \mathrm{X}_{1}$ : airborne aerobe $(\mathrm{CFU} / \mathrm{mE} 3) ; \mathrm{X}_{2}$ : airborne gram-negative bacteria $(\mathrm{CFU} / \mathrm{mE} 3)$

$\mathrm{Y}=4.76+2.41 \times 10 \mathrm{E}-6 \mathrm{X}_{1}+1.00 \times 10 \mathrm{E}-4 \mathrm{X}_{2}-1.03 \times$ $10 \mathrm{E}-4 \mathrm{X}_{3}, R^{2}=0.9760, p=0.0230$

Y: H5 AIV antibody titer $(-\log 2) ; \mathrm{X}_{1}$ : airborne aerobe $(\mathrm{CFU} / \mathrm{mE} 3) ; \mathrm{X}_{2}$ : airborne fungi $(\mathrm{CFU} / \mathrm{mE} 3) ; \mathrm{X}_{3}$ : airborne endotoxin $(\mathrm{EU} / \mathrm{mE} 3)$

$\mathrm{Y}=55.61-5.01 \times 10 \mathrm{E}-4 \mathrm{X}_{1}+6.01 \times 10 \mathrm{E}-6 \mathrm{X}_{2}-1.03 \times$ $10 \mathrm{E}-4 \mathrm{X}_{3}, R^{2}=0.8795, p=0.0141$

Y: IL-2 (ng/mL); $X_{1}$ : airborne fungi (CFU/mE3); $X_{2}$ : airborne gram-negative bacteria $(\mathrm{CFU} / \mathrm{mE} 3) ; \mathrm{X}_{3}$ : airborne endotoxin (EU/mE3)

$\mathrm{Y}=43.77-5.53 \times 10 \mathrm{E}-6 \mathrm{X}_{1}+1.01 \times 10 \mathrm{E}-4 \mathrm{X}_{2}+3.69 \times$ $10 \mathrm{E}-6 \mathrm{X}_{3}-3.03 \times 10 \mathrm{E}-4 \mathrm{X}_{4}, R^{2}=0.8417, p=0.0392$

$\mathrm{Y}$ : T-lymphocyte transformation rate (\%); $\mathrm{X}_{1}$ : airborne aerobe $(\mathrm{CFU} / \mathrm{mE} 3) ; \mathrm{X}_{2}$ : airborne fungi $(\mathrm{CFU} / \mathrm{mE} 3) ; \mathrm{X}_{3}$ : airborne gram-negative bacteria $(\mathrm{CFU} / \mathrm{mE} 3) ; \mathrm{X}_{4}$ : airborne endotoxin (EU/mE3)

$\mathrm{Y}=155.45-8.35 \times 10 \mathrm{E}-6 \mathrm{X}_{1}-1.99 \times 10 \mathrm{E}-6 \mathrm{X}_{2}-2.00 \times$ $10 \mathrm{E}-4 \mathrm{X}_{3}, R^{2}=0.9097, p=0.0517>0.05$ 
Y: Lysozyme $(\mathrm{U} / \mathrm{mL}) ; \mathrm{X}_{1}$ : airborne fungi (CFU/mE3); $\mathrm{X}_{2}$ : airborne gram-negative bacteria $(\mathrm{CFU} / \mathrm{mE} 3) ; \mathrm{X}_{3}$ : airborne endotoxin (EU/mE3)

From the analysis above, it could be concluded that the concentration of airborne aerobe, fungi, gram-negative bacteria, endotoxin have a strong correction with the value of H5 AIV antibody titer, IgG, IL-2, T-lymphocyte rate, lysozyme, and immune organ indexes, respectively. Thus, it can provide a substantial evidence to confirm the effect of microbial aerosol on immune level.

\section{DISCUSSION}

Microbial aerosol originates from feed, manure, litter, as well as microorganisms, their byproducts and fragments in poultry houses (Millner, 2009; Just et al., 2011). Airborne aerobes, fungi, gram-negative bacteria and their bioproducts or biological fragments (such as endotoxins) are major components (Yu et al., 2016). The concentrations and components of it could reflect the condition of ambient sanitation in animal houses (Zucker and Muller, 2000; Kaliste et al., 2002). High concentrations of microbial aerosol and its metabolites (endotoxin, $\mathrm{NH}_{3}$, $\mathrm{H}_{2} \mathrm{~S}$, etc) are important factors affecting the health and productivity of animals (Prazmo et al., 2003; Banhai et al., 2008).

In this study, four treatment groups with gradually deteriorating hygienic conditions and one control group under standard hygienic sanitary management were set up by changing the frequency of trough cleaning, sterilization, bedding replacement, and ventilation (Table 1). The concentrations of airborne aerobes, fungi, gram-negative bacteria, and endotoxin in groups B, C, D increased both over time and as hygienic conditions deteriorated (Table 2). The results show that routine hygienic management measures, such as ventilation, bedding replacement and sterilization can reduce bioaerosols in duck poly-tunnels, which is important in order to maintain optimal microclimate and hygiene. Phosphoric acid, calcium superphosphate, ferrous sulfate, caustic lime, acticarbon, and alum were effective in absorbing noxious gases.

To the best of our knowledge, this study is the first to evaluate the effects of microbial aerosol on duck immunity. As we all known, immunity of animal can be divided into specific and non-specific immunity, and specific immunity can be divided into humoral and cellular immunity. In order to explore the effects of microbial aerosol on the immune function of duck. We chose IgG, H5 AIV antibody titer as reliable indicators for humoral immunity; took IL-2, T-lymphocyte transformation rate as representativeness indexes for cellular immunity; and took lysozyme, Immune organ indexes as non-specific immune factors.

Immunity to avian influenza is mainly based on humoral immunity, and detection of antibody titer of avian influenza contributes to indicating the condition of specific immune system protection (Ellis et al., 2004; Liu et al., 2006). As for serum IgG, it is the highest level of immunoglobulin in the blood of bodies. The activity of anti-bacteria, anti-virus and antitoxin of IgG can be embodied in animal blood, and it plays essential roles in "Main Immune" (Borghesi et al., 2014). IL-2, also called T-cell growth factor, is the main cytokine in regulating cellular immune (Bayer et al., 2013). It is mainly produced by activated T-lymphocytes, and also can activate a variety of immune cells, regulate the body's immunity and enhance the body's anti-inflammatory effects, etc. (Song et al., 2005). In the process of the immune response, T-lymphocyte transformation rate is involved in the cellular immune response, therefore, it is often used to assess the functional status of lymphocytes and the status of body's immunity (Toivanen and Toivanen, 1973; Hovi et al., 1978; Kim et al., 1996).

Lysozyme is a kind of hydrolase that has special effects on the microbial cytoderm, which relaxes cytoderm and loses the protective effect on cells, and results in bacteria dissolution eventually (Sung et al., 2011). In the process of anti-bacterial infection, lysozyme often used as an important indicator that reflects strength of non-specific immunity (Fiolka et al., 2012; Zhao et al., 2014). The weight of thymus, spleen and bursa can be used to evaluate the immune status of poultry. It also reflects the strength of immune function intuitively (Rivas and Farbricant, 1985).

Over the experimental period, as microbial aerosol concentration increasing, serum IgG and lysozyme (4 and 5 weeks) increased, whereas H5 AIV antibody titer, IL-2, T-lymphocyte transformation rate, lysozyme (6 and 8 weeks), and immune organ indexes decreased. When the concentration of microbial aerosol reach the level of group D, serum IgG (6-8 weeks), serum lysozyme (4 week) were significantly higher than in group A $(P<0.05)$; serum IL-2 (7 and 8 weeks), T-lymphocyte transformation rate, serum lysozyme (7 and 8 weeks), spleen index (6 and 8 weeks), and bursa index ( 8 week) were significantly lower than in group A $(P<0.05$ or $P<0.01)$.

Microbial aerosols at certain concentrations can stimulate the stress response, and stress can have serious adverse effects on welfare (Yu et al., 2016). Under stress, animals have to activate energy to combat the stressor, which can enhance catabolism and weaken the anabolism of protein and fat. Where animals are reared in environments contaminated with microorganisms, the nutrient status of organs may be compromised (Benson et al., 1993). This might be the reason for the decreasing tendency of immune organ indexes.

Moreover, if the stress in a long period of time, and it could lead to chronic stress, which could lead to cellular immune inhibition (Schedlowski, 1993; Bartolomucci et al., 2003), cutting down the production of IL-2 in serum (McEwen et al., 1997). This might be the reason for the tendency of serum IL-2 and T-lymphocyte transformation rates.

As for the tendency of serum IgG and lysozyme, after the initial increase it later decreased (6-8 weeks; Figure 2 and Table 3), this may be due to the appearance of "malignant stress" in the late stages of this study, that is, under the short-term and mild stress, animals could adapt to it by compensatory reaction, but the long-term stress at any intensity will result in harmful effects, such as deterioration of physiological function in animals, etc. (He et al., 2011). 
In addition, high level of microbial aerosol also affected the humoral immunity level of meat ducks, and it not only reduced the H5 AIV antibody titer of ducks, but also delayed the emergence of the antibody titer peak (Figure 1). This result is analogous to that of Witter (1998). Witter argued that weakened immune function reduces the immune protective effect of the vaccine.

\section{CONCLUSIONS}

In conclusion, a high level of airborne aerobe, gram-negative bacteria, fungi, and endotoxin adversely affected the immune level of meat ducks. This study indicates that good ventilation, bedding replacement and sterilization can decrease microbial aerosol concentration effectively. The present findings suggest that the microbial aerosol concentrations of group $\mathrm{D}$ provide a basis for recommending upper limit concentrations of microbial aerosols for healthy meat ducks.

\section{REFERENCES}

Andersen, A. A. (1958). New sampler for collection, sizing and enumeration of viable airborne particles. J. Bacteriol. 76, 471-484.

Balasubramanian, R., Nainar, P., and Rajasekar, A. (2012). Airborne bacteria, fungi, and endotoxin levers in residential microenvironments: a case study. Aerobiologia 28, 375-390. doi: 10.1007/s10453-011-9242-y

Banhai, T. M., Seedorf, J., Laffrique, M., and Rutley, D. L. (2008). Identification of the risk factors for high airborne particle concentrations in broiler buildings using statistical modeling. Biosyst. Eng. 101, 100-110. doi: 10.1016/j.biosystemseng.2008.06.007

Barrasa, M., Lamosa, S., Fernandez, M. D., and Fernandez, E. (2012). Occupational exposure to carbon dioxide, ammonia and hydrogen sulphide on livestock farms in the north-west Spain. Ann. Agric. Environ. Med. 19, 17-24.

Bartolomucci, A., Sacerdote, P., and Panerai, A. E. (2003). Chronic psychosocial stress induced down-regulation of immunity depends upon individual factors. J. Neuroimmunol. 141, 58-64. doi: 10.1016/S0165-5728(03)00220-0

Bayer, A. L., Pugliese, A., and Malek, T. R. (2013). The IL-2/IL-2R system: from basic science to therapeutic applications to enhance immune regulation. Immunol. Res. 57, 197-209. doi: 10.1007/s12026-013-8452-5

Benson, B. N., Calvert, C. C., Roura, E., and Klasing, K. C. (1993). Dietary energy source and density modulate the expression of immunologic stress in chicks. J. Nutr. 123, 1714-1723.

Borghesi, J., Lara, C. M., Rodrigues, M. N., Favaron, P. O., and Miglino, M. A. (2014). Immunoglobulin transport during gestation in domestic animals and humans-a review. Open J. Anim. Sci. 4, 323-336. doi: 10.4236/ojas.2014. 45041

Brachmann, P. S., Ehrlich, R., Eichenwald, H. F., Heninz, F., Gabelli, V. J., Kethley, T. W., et al. (1964). Standard sampler for assay of airborne microorganisms. Science 144, 1295.

Burrell, R. (1990). Immunomodulation by bacterial endotoxin. Crit. Rev. Microbiol. 17, 189-208. doi: 10.3109/10408419009105725

Bush, R. K., and Portnoy, J. M. (2001). The role and abatement of fungal allergens in allergic diseases. J. Allergy Clin. Immunol. 107, 430-440. doi: 10.1067/ mai.2001.113669

Cambra-López, M., Aarnink, A. J. A., Zhao, Y., Calvet, S., and Torres, A. G. (2010). Airborne particulate matter from livestock production systems: a review of an air pollution problem. Environ. Pollut. 158, 1-17. doi: 10.1016/ j.envpol.2009.07.011

Do, J. C., Choi, I. H., and Nahm, K. H. (2005). Effects of chemically amended litter on broiler performance, atmospheric ammonia concentration, and phosphorus solubility in litter. Poult. Sci. 84, 679-689. doi: 10.1093/ps/84.5.679

\section{AUTHOR CONTRIBUTIONS}

GY and YC designed the experiment and completed most of the works. YW, SW, CD, and JG analyzed some test results and collected materials. TC and LW gave experiment instruction. Thank all the authors' contribution to the experiment.

\section{ACKNOWLEDGMENTS}

This research was funded by The National Science and Technology Support Project "Research of airborne microorganisms of animal houses and their impact on the Animal Health and Control Technology" [2012BAD39B0205]; Natural Science Foundation of Shandong Province [ZR2012CM041]; Natural Science Foundation of Shandong Province [ZR2011HM032]; State Environmental Protection Key Laboratory of Microorganism Application and Risk Control (MARC), Tsinghua University, China [SMARC2013D001].

Douwes, J., Thorne, P., Pearce, N., and Heederik, D. (2003). Bioaerosol health effects and exposure assessment: progress and prospects. Ann. Occup. Hyg. 47, 187-200. doi: 10.1093/annhyg/meg032

Duan, H., Chai, T., Zhang, X., and Ma, R. (2007). Microbiological aerosols in poultry house and its ambience. ISAH-2007 Tartu. Estonia 2007, 526-232.

Duncan, D. B. (1955). Multiple range and multiple F tests. Biometrics 11, 1-42. doi: $10.2307 / 3001478$

Ellis, T. M., Leung, C. Y., Chow, M. K., Bissett, L. A., Wong, W., and Guan, Y. (2004). Vaccination of chickens against H5N1 avian influenza in the face of an outbreak interrupts virus transmission. Avian Pathol. 33, 405-412. doi: 10.1080/03079450410001724012

Fiegel, J., Clarke, R., and Edwarde, D. A. (2006). Airborne infectious disease and the suppression of pulmonary bioaerosols. Drug Discov. Today 11, 51-57. doi: 10.1016/S1359-6446(05)03687-1

Fiolka, M. J., Zagaja, M. P., Hulas-Stasiak, M., and Wielbo, J. (2012). Activity and immunodetection of lysozyme in earthworm Dendrobaena veneta (Annelida). J. Invertebr. Pathol. 109, 83-90. doi: 10.1016/j.jip.2011.10.002

He, Z. M., Li, G. P., Li, G. M., Chen, Z. W., and Wang, L. Z. (2011). "Laboratory animal welfare and animal experimental science," in Laboratory Animal Welfare, eds Z. M. He and G. P. Li (Beijing: Science Press), 104-106.

Hovi, T., Suni, J., Hortling, L., and Vaheri, A. (1978). Stimulation of chicken lymphocytes by $\mathrm{T}$ and $\mathrm{B}$ cell mitogens. Cell. Immunol. 39, 70-78. doi: 10.1016/0008-8749(78)90084-9

Hsiao, I. L., and Huang, Y. J. (2011). Improving the interferences of methyl thiazolyl tetrazolium and IL-8 assays in assessing the cytotoxicity of nanoparticles. J. Nanosci. Nanotechnol. 11, 5228-5233. doi: $10.1166 /$ jnn.2011.4132

Just, N., Kirychuk, S., Gilbert, Y., Letourneau, V., Veillette, M., and Singh, B. (2011). Bacterial diversity characterization of bioaerosols from cagehoused and floor-housed poultry operations. Environ. Res. 11, 492-498. doi: 10.1016/j.envres.2011.01.009

Kaliste, E., Linnainmaa, M., Meklin, T., and Nevalainen, A. (2002). Airborne contaminants in conventional laboratory rabbit rooms. Lab. Anim. 36, 43-50. doi: 10.1258/0023677021911759

Kim, H. M., Han, S. B., Oh, G. T., Kim, Y. H., Hong, D. H., Hong, N. D., et al. (1996). Stimulation of humoral and cell mediated immunity by polysaccharide from mushroom Phellinus linteus. Int. J. Immunopharmacol. 18, 295-303. doi: 10.1016/0192-0561(96)00028-8

Lawniczek-Walczyk, A., Górny, R. L., Golofit-Szymczak, M., Niesler, A., and Wlazlo, A. (2013). Occupational exposure to airborne microorganisms, endotoxins and $\beta$-glucans in poultry houses at different stages of the production cycle. Ann. Agric. Environ. Med. 20, 259-268. 
Lazar, V., Chifiriuc, M. C., Steward-Tull, D. E., Bleotu, C., Candlich, D., and Wardlaw, A. C. (2010). Investigation of the cytotoxic capacity of some adherent opportunistic enterobacterial strains by the MTT assay and transmission electron microscopy. Roum. Arch. Microbiol. Immunol. 69, 35-40.

Liu, C. N., Liu, M., Zhang, Y., Liu, C. G., and Gao, X. L. (2006). Pathogenicity of H5N1 influenza virus for ducks. Sci. Agric. Sin. 39, 412-417.

Madsen, A. M. (2006). Airborne endotoxin in different background environments and seasons. Ann. Agric. Environ. Med. 13, 81-86.

Masclaux, F. G., Sakwinska, O., Charrière, N., Semaani, E., and Oppliger, A. (2013). Concentration of airborne Staphylococcus aureus (MRSA and MSSA), total bacteria, and endotoxins in pig farms. Ann. Occup. Hyg. 57, 550-557. doi: 10.1093/annhyg/mes098

Matković, K., Vučemilo, M., Štoković, I., Šimić, R., Marušić, D., Vinković, B., et al. (2013). Concentrations of airborne bacteria and fungi in a livestock building with caged laying hens. Vet. Arh. 83, 413-424.

McEwen, B. S., Biron, C. A., and Brunson, K. W. (1997). The role of Adrenocorticoids as modulates of immune function in health and disease: neural, endocrine and immune interactions. Brain Res. Rev. 23, 79-133. doi: 10.1016/S0165-0173(96)00012-4

Millner, P. D. (2009). Bioaerosols associated with animal production operations. Bioresour. Technol. 100, 5379-5385. doi: 10.1016/j.biortech.2009.03.026

Moore, P. A., Daniel, T. C., Edwards, D. R., and Miller, D. M. (1996). Evaluation of chemical amendments to reduce ammonia volatilization from poultry litter. Poult. Sci. 75, 315-320. doi: 10.3382/ps.0750315

Nimmermark, S., Lund, V., Gustafsson, G., and Eduard, W. (2009). Ammonia, dust and bacteria in welfare-oriented systems for laying hens. Ann. Agric. Environ. Med. 16, 103-113.

Pavan, R., and Manjunath, K. (2014). Qualitative analysis of indoor and outdoor airborne fungi in cowshed. J. Mycol. 2014, 1-8. doi: 10.1155/2014/ 985921

Pirie, R. S., Collie, D. D., and Dixon, P. M. (2003). Inhaled endotoxin and organic dust particulates have synergistic proinflammatory effects in equine heaves (organic dust-induced asthma). Clin. Exp. Allergy 33, 676-683. doi: 10.1046/j.1365-2222.2003.01640.x

Prazmo, Z., Dutkiewicz, J., Skórska, C., Sitkowska, J., and Cholewa, G. (2003). Exposure to airborne Gram-negative bacteria, dust and endotoxin in paper factories. Ann. Agric. Environ. Med. 10, 93-100.

Rivas, A. L., and Farbricant, J. (1985). Indication of Immundepression in chicken infected with various of Marek's Disease Virus. Avian Dis. 32, 1-8. doi: 10.2307/ 1590941

Schedlowski, M. (1993). Psychophysiological neuroendocrine and cellular immune reactions under psychological stress. Neuropsychobiology 28, 87-90. doi: $10.1159 / 000119006$

Song, Q. Y., Guo, X., and Yang, H. C. (2005). Porcine cytokines (In Chinese). Chinese J. Vet. Med. 41, 33-38.

Sung, K., Khan, S. A., Nawaz, M. S., Cerniglia, C. E., Tamplin, M. L., Phillips, R. W., et al. (2011). Lysozyme as a barrier to growth of Bacillus anthracis strain sterne in liquid egg white, milk and beef. Food Microbiol. 28, 1231-1234. doi: 10.1016/j.fm.2011.03.002

Teye, F. K., Hautala, M., Pastell, M., Praks, J., Veermae, I., Poikalainen, V., et al. (2008). Microclimate and ventilation in Estonian and Finnish dairy buildings. Energy Build. 40, 1194-1201. doi: 10.1016/j.enbuild.2007. 10.017

Toivanen, P., and Toivanen, A. (1973). Selective activation of chicken T lymphocytes by Concanavalin A. J. Immunol. 111, 1602-1603.

Witter, R. L. (1998). Control strategies for Marek's Disease: a perspective for the future. Poult. Sci. 77, 1197-1203. doi: 10.1093/ps/77.8.1197

Wolinsky, S. M. (2006). Public health: chicken monster or chicken little? Science 311, 780-781. doi: 10.1126/science.1123435

Yao, Z. Q., and Li, Y. C. (2010). Effects of harmful gas in poultry house on livestock and its control measures (In Chinese). Livestock and Poultry Industry, 258, 22-23.

Yin, W., Ma, Q. H., Jiang, J. B., Fan, K. H., Sun, N., and Sun, Y. G. (2015). Effects of Astragalus Polysaccharides (APS) on T Lymphocyte proliferation regulated by red blood cells (In Chinese). Prog. Vet. Med. 36, 53-58.

Yu, G. L., Wei, L. M., Liu, Y. Y., Liu, J. Y., Wang, Y., Gao, J., et al. (2016). Influence of indoor microbial aerosol on the welfare of meat ducks. Br. Poult. Sci. 57, 12-22. doi: 10.1080/00071668.2015.1122739

Zhao, M., Song, Q. R., Dai, G. Z., and Wang, L. (2014). Influence of long-term high-temperature environment on immune system of rats. Occup. Health 18, 2568-2570.

Zucker, B. A., and Muller, W. (2000). Investigation on airborne microorganisms in animals stables. 3: relationship between inhalable endotoxin, inhalable dust and airborne bacteria in a hen house. Berl. Munch. Tierarztl. Wochenschr. 113, 279-283.

Zucker, B. A., Trojan, S., and Muller, W. (2000). Airborne gram-negative bacterial flora in animal houses. J. Vet. Med. Ser. B 47, 37-46. doi: 10.1046/j.14390450.2000.00308.x

Conflict of Interest Statement: The authors declare that the research was conducted in the absence of any commercial or financial relationships that could be construed as a potential conflict of interest.

The handling Editor declared a shared affiliation, though no other collaboration, with authors GY, YW, LW, TC, YC and states that the process nevertheless met the standards of a fair and objective review.

Copyright (c) 2016 Yu, Wang, Wang, Duan, Wei, Gao, Chai and Cai. This is an open-access article distributed under the terms of the Creative Commons Attribution License (CC BY). The use, distribution or reproduction in other forums is permitted provided the original author(s) or licensor are credited and that the original publication in this journal is cited, in accordance with accepted academic practice. No use, distribution or reproduction is permitted which does not comply with these terms. 